Engineering History and Heritage Volume 168 Issue EH2

Hinges in historic concrete and masonry arches

Holzer and Veihelmann
Proceedings of the Institution of Civil Engineers Engineering History and Heritage 168 May 2015 Issue EH2 Pages 55-64 http://dx.doi.org/10.1680/ehah.14.00019 Paper 1400019

Received 25/08/2014

Published online 24/02/2015

Keywords: bridges/concrete structures/history

\title{
Hinges in historic concrete and masonry arches
}

1 Stefan M. Holzer Dr-Ing

Professor, Institute BAU-1, Department of Civil and Environmental Engineering, University of the Federal Armed Forces Munich, Neubiberg, Germany
2. Karen Veihelmann Dipl Ing, MA

Research Assistant, Institute BAU-1, Department of Civil and Environmental Engineering, University of the Federal Armed Forces Munich, Neubiberg, Germany
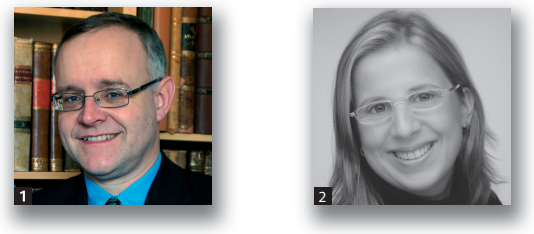

The three-hinged arch, while increasingly common in steel bridge construction from the 1860s, was introduced more reluctantly into masonry and concrete bridge building. However, by the end of the nineteenth century, it had found widespread application, particularly in Germany. Considerations of crack prevention as well as ease and consistency of the mechanical modelling of masonry arches were evidently the driving forces behind this development. The present paper describes the history of the hinged vaulted bridge, from the first suggestions by the eminent French engineer Jules Dupuit (published in 1870) up to the early years of the twentieth century. Particular attention is given to temporary and 'imperfect' hinges which may be neither visible nor active in the finished state of the bridge, and to the historic development and design of permanent hinges, outlining the range of constructive solutions the modern engineer may encounter when assessing the state of a late nineteenth century vaulted bridge.

\section{Introduction}

Every masonry arch experiences some deformation during its construction. When laying the individual rows of voussoirs, the increasing load will cause some deflection of the centre and, by consequence, induce deformations of the parts of the incomplete arch which already rest on the centre. Once the keystone has been set and the centre has been struck, the arch carries its own weight by itself, causing further changes of form due to the elastic (or, indeed, plastic) compression of the arch material (voussoirs and mortar joints), and perhaps also some yielding of the abutments. Typically, a finished arch reveals, upon close inspection, some amount of inevitable cracking at the 'joints of rupture' - that is, at the extrados of the springings and at the intrados at the apex.

The movements associated with the construction of an arch, however, do not necessarily lead to extensive, conspicuous crack formation. Arches built with small stones such as brick or rubble, and thick joints filled with soft (lime) mortar, will essentially adapt their shape by changes of the local thickness of the mortar joints. The empirical observation of this fact encouraged, for many centuries, the practice of early decentring, when the mortar was still plastic.
This has, without doubt, a lot of advantages, because the mortar is still in a state of being able to be compressed and to accommodate itself to new shapes, without any disorganisation being entailed. It seems therefore that one must build the vaults and strike the centres as early as possible, in order to avoid that the mortar has already hardened completely in the moment of decentring. (Dejardin, 1845: p. 263)

By contrast, arches built with large ashlar blocks and thin mortar joints, particularly in connection with the use of quickly hardening, high-strength (cement) mortar, are liable to obtrusive cracking. Therefore, it is not surprising that the study of arch deformation during the construction process began to attract engineers during the late eighteenth century, particularly in France, where elaborate large-span ashlar bridges were popular at that time. A detailed study of movements and cracking of masonry arches was performed, for example, by Boistard (1810).

Such observations naturally triggered attempts to improve the construction process. To mention just a few, use of stiff centres, pre-loading of the centres and smooth decentring procedures were tried (for a survey, see Holzer (2012)). However, all of these techniques were useful only during the construction process and did little to avoid later cracking of the masonry arch caused by 
Engineering History and Heritage

Volume 168 Issue $\mathrm{EH} 2$
Hinges in historic concrete and

masonry arches

Holzer and Veihelmann abutment yield, temperature effects, or unsymmetric accidental loading. All of these aspects could only be addressed simultaneously by the introduction of permanent hinges, transforming the masonry arch into an isostatic structure. Contemporary steel construction furnished precedents for the design of such hinges, but masonry construction also found its own idiosyncratic solutions. The present paper traces the introduction and development of the different types of hinges in masonry and concrete arches from their beginnings to World War I.

\section{Innovative construction techniques}

With the introduction of quickly hardening, high-strength Portland cement mortars around 1850, masonry bridges with unprecedented spans became feasible. At roughly the same time, expensive ashlar was replaced by cheap 'small materials' such as brick, rubble stone and, finally, concrete. Arch bridges in almost monolithic, concrete-like construction began to spread over continental Europe (see Darcel (1855) for a list). However, such bridges tended to crack conspicuously, because the inevitable cracks were no longer aligned with and hidden inside regular bed joints.

\section{Because the mortar hardens almost instantaneously, the whole vault will act like a single voussoir after its completion; by consequence, it is necessary to avoid the cracks which normally appear at the springings and at the haunches of an arch during its construction; these cracks are almost always caused by the deformation of the centres which develops when they are loaded. (Claudel and Laroque, 1850: p. 300)}

This problem was tackled by innovative construction processes when the rubble-cement arch of Pont aux Doubles was erected in Paris in 1847: the arch was built in four large, voussoirshaped chunks, separated from each other by open gaps at the springings, at the haunches and at the apex (Figure 1). These spaces were filled only at the very last moment, so that the individual sections of the arch were enabled to rotate freely until almost the full charge of the masonry arch rested on the centre (Claudel and Laroque, 1850: pp. 301-302).

This method was complemented by vaulting in rings; in other words, the arch was doubled up to its full depth only after the first, thin arch had been completed. In this way, the first ring could serve as a reinforcement to the centre and would help to carry the load of the remainder of the arch. While vaulting in independent rings had been introduced to bridge building in Great Britain (e.g. Brunel's brick arch Wharncliffe viaduct, 1837), the continental bridge builders paid increased attention to perfect bonding of the rings ('one took all the necessary precautions to ensure the adherence of the new masonry to the first ring', Claudel and Laroque (1850): p. 301). The novel masonry arch construction strategies - vaulting in sections, delayed filling of the last open joints and vaulting in rings

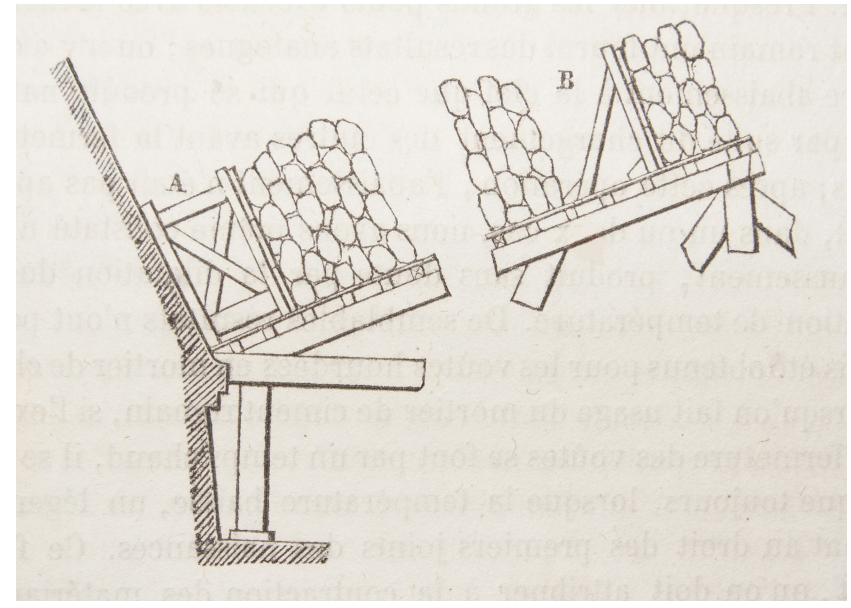

Figure 1. Construction of an arch with cement mortar and rubble stones in chunks separated by gaps to be filled up at the end (Claudel and Laroque, 1850: p. 301)

- were perfected during the last third of the nineteenth century, notably through the work of Paul Séjourné, who published a famous memoir on the topic in 1886 (Séjourné, 1886). Not all of these techniques, however, lent themselves equally well to concrete construction.

Contemporary iron bridge construction, conversely, was determined by completely different considerations. Iron continued to be a fairly expensive material (notably in Germany); therefore, it had to be used economically. Consequently, the development of structural analysis in order to determine minimum member sizes and an optimal system layout was mainly driven by iron (bridge) construction. Preconditions for a suitable structural analysis included the design of systems in strict accordance with the assumptions of their computational model, and above all, the selection of easy-to-compute structures. Particularly in the second half of the nineteenth century, these requirements tended to favour isostatic structures such as three-hinged arches over hyperstatic structures such as the clamped arch. Isostatic structures also had the invaluable advantage of not being subject to constraints such as incalculable abutment movements or temperature changes, which might otherwise have compromised the clear starting assumptions of the analysis, leading to unforeseen and unpredictable stresses in the structure. These ideas were summarised concisely by François-Hippolyte Mantion (1825-1897), the engineer in charge of a paradigmatic hinged iron railway bridge at Saint-Denis (1858): 'Thus, by putting our arch on pivots, we have reduced the effects of temperature changes, and we have been able to compute them.' (Mantion, 1860: p. 190). Hinged metal arch bridges spread from the 1860 s, including the two-hinge railway bridges at KoblenzPfaffendorf (1862-1864) as well as Gustave Eiffel's viaducts at 
Engineering History and Heritage

Volume 168 Issue EH2
Hinges in historic concrete and

masonry arches

Holzer and Veihelmann
Porto (1877) and Garabit (1880-1884), and the fully developed three-hinge arches such as Jean Résal's Pont Alexandre III, Paris (1898-1900), to mention just a few outstanding examples (for the early history of hinges in steel construction in general, see Lorenz (1990)).

On the other hand, precise dimensioning of the individual members of the structure was not a prime concern in masonry arch bridge construction, and particularly not in constructions employing small materials such as rubble or concrete and cementitious mortar. Rather, structural analyses of masonry arches during the second half of the nineteenth century tended to ensure the structural safety by prescribing a region of 'permissible lines of thrust' inside the proposed arch - there being no other choice anyhow since contemporary methods of arch analysis such as Méry's method of 1840 (Méry, 1840) or Durand-Claye's method (Durand-Claye, 1867) excluded the notion of elasticity of the arch and were therefore naturally restricted to the definition of 'safe design regions' rather than pinpointing the exact state of stress inside the arch and the precise factor of safety (cf. the view of Mantion (1860): p. 163: 'The method of thrust lines leaves a lot to be desired'!). The introduction of the theory of elasticity into masonry arch construction, providing the missing uniqueness of the analysis, if achieved as early as 1879 by Emil Winkler (1835-1888) (cf. Winkler, 1879/1880), failed to find much resonance with masonry arch bridge builders for the next decades. Rather, masonry arches tended to be designed according to the 'middle third rule' during the last third of the nineteenth century (see, for example, Tolkmitt (1895): p. 39). This method relied on the construction of an arbitrary line of thrust passing through three selected points on the boundary of the middle third of the arch. Designs based on this rule would ensure that the arch was fully compressed. The engineer would accept the arch design as safe unless the line of thrust passed outside the permissible region somewhere. In addition, the perceived 'uncertainty as to the real state of stress' (Tolkmitt, 1895: p. 39) was compensated in an approximate manner by an ample factor of safety of $1 / 10$ on the compressive strength of the masonry (Tolkmitt, 1895: p. 40).

\section{Driving forces behind the introduction of hinges in masonry arches}

Notwithstanding these established ways of analysis, design and construction, the last third of the nineteenth century witnessed the introduction of artificial hinges into masonry arch construction. The driving forces behind this were twofold: the first was practical, the introduction of hinges at the right places of the arch allowed the parts of the arch to rotate freely, eliminating the major cracking concerns during the different stages of construction; the second was theoretical, the masonry arch thus became isostatic, eliminating the need of elastic analysis and also the detrimental effects of abutment yield, long-term creep of the mortar joints, and other problems related to the service lifetime of the arch. Incidentally, with a view to the difficulties associated with determining the elastic properties of masonry, it is not surprising that hinged masonry bridge arches - unlike their steel counterparts - always have three hinges, if any at all.

The very first suggestions to introduce hinge-like elements into masonry arch construction can be traced to France, and more specifically, to Jules Dupuit (1804-1866). In his posthumously published Traité de l'Equilibre des Voûtes (Dupuit, 1870), he strove to extend the applicability of masonry to spans not dreamt of hitherto.

It is remarkable that the moderns should have achieved so little progess on the span of masonry bridges. Whenever great spans have to be bridged, one has recourse to cast iron or sheet metal; is this a necessity? We will answer this question in a later chapter, but for now, we will present new measures to be taken during the construction of wide-span arches, which will allow the extension of their spans, in full safety. (Dupuit, 1870: p. 194).

Next, Dupuit perceives the uncertainty as to the real position of the line of thrust inside the arch, and the impossibility of prescribing the shape of this curve in a hyperstatic system, as the dominant drawbacks of classical masonry arches. Therefore, he suggests a contrivance to be applied at the haunches of the arch

which would consist in replacing the joint on the intrados side by a line forming an obtuse angle with it, adapted to the remainder of the joint by a curve which would enable the arch to roll on it, provided this part of the joint would not be mortared, but just stuffed with tow. This way, one would determine a point through which the line of thrust would be obliged to pass, and which one could place voluntarily at any distance from the intrados; one could even do something similar at the apex. (Dupuit, 1870: p. 195)

Dupuit's text is accompanied by a simple figure showing a voussoir with a chamfered edge at the intrados (Figure 2). Dupuit stresses that this hinge-like arrangement would 'eliminate all indeterminateness from the drawing of the line of thrust' (Dupuit, 1870). Evidently, Dupuit's main concern is improving the relation between the structure as calculated and as built.

Concerning the practical application of his proposal, Dupuit provides further detail.

It is unnecessary that the hinge should be located exactly at the rupture joint; theoretically, it will have the same effect anywhere. But as a straight line is defined the better by two points the farther those points are distant from each other, the better is it here to fix the point where the line of thrust passes, as far from the apex as possible; also, we believe that the hinge should be placed at a point where what happens can be observed easily, and where the joint can 
Hinges in historic concrete and

masonry arches

Holzer and Veihelmann

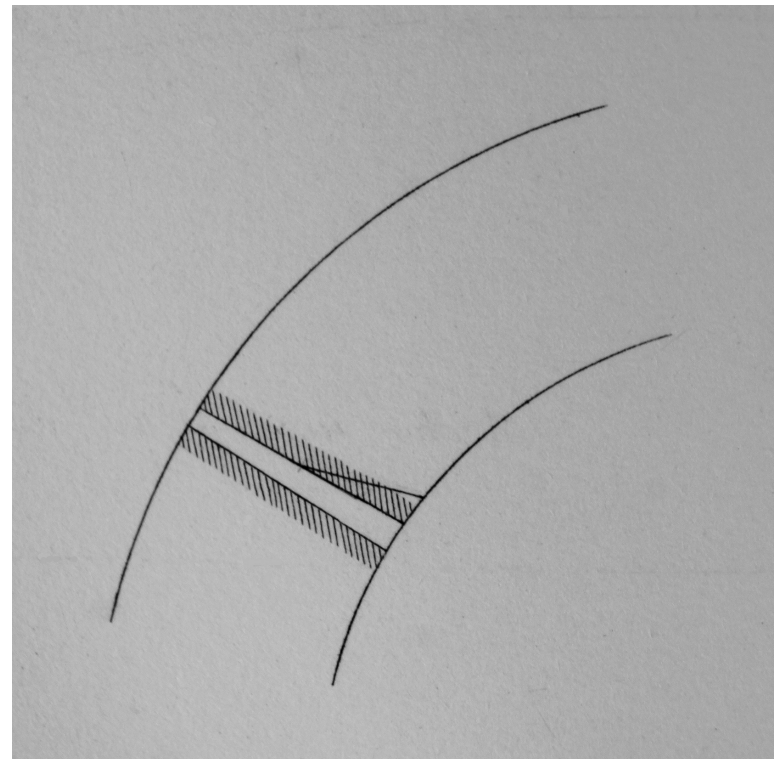

Figure 2. Jules Dupuit's sketch of an artificial hinge in a masonry arch (Dupuit, 1870, plate 6, detail)

be mortared as easily from the extrados as from the intrados. In a vault constructed like that, the rotation, in the moment of decentring, will necessarily occur around the point of contact, which one could place 2 or 3 centimetres away from the edge. [...] Furthermore, as we have already stated, one could employ stone of superior strength for the two courses of voussoirs. [...] One might also increase the strength by putting two cast iron plates at the point of contact [...] Finally, a sheet of plumb of 3 or 4 millimetres thickness could be arranged between the two metallic surfaces to avoid concentrated contact pressure; once the arch has been decentred, the hinge joint, filled up with mortar, will not differ at all from the other joints of the vault. (Dupuit, 1870: pp. 195-197).

However, notwithstanding Dupuit's detailed suggestions, the introduction of hinges into masonry arches found few friends in contemporary France. Although Alphonse Debauve, in his widely read instruction Manuel de l'Ingénieur des Ponts et Chaussées, repeated Dupuit's recommendations in the 1873 volume on stone arch bridges, and even suggested the use of a cast iron bolt ('one should leave these two joints dry, and place in their middle, normal to the faces of the bridge, e.g., a cylinder of cast iron, which is in turn clasped by two other castiron cylinders which are attached to the two adjacent parts of the vault', Debauve, 1873: p. 95), no such construction was attempted in reality in France at that time. The only exception is the design of the central arch of the Tolbiac Bridge, Paris, executed in rubble masonry with cement mortar 1879-1880. In a memoir of 1878 , the engineer in charge of this bridge, Gustave-Pierre Brosselin, came back to Dupuit's suggestion of forming three hinges, employing ashlar blocks of superior quality and to use this higher strength to reduce the length of the joint (Brosselin, 1878: pp. 1-2). Although he claimed to have applied the idea at the central arch of the Tolbiac Bridge (Brosselin, 1878: p. 2; before construction was actually started!), there are at least four contemporary papers contesting that the idea was actually put into practice. The bridge does still exist, but it is impossible to tell whether the joint at the crown was open during decentring; anyhow, there is nothing to indicate the presence of a hinge. With this sole exception, hinges in vaulted bridges remained uncommon in France until 1913, when the aged Paul Séjourné found reason to complain.

In 1870, Dupuit proposed, as the first, the introduction of hinges in arches. However, this French idea has been ill received in France: one does not apply it. By contrast, it has been welcomed in Germany: Since 30 years, one builds hinged vaults there. (Séjourné, 1913: p. 3)

Séjourné's insistence on the French origin of the idea is disputable, since hinged arches have also been suggested by the German author Friedrich Heinzerling (1824-1906) during the same period and with similar motivation. In an article on graphical statics of bridge arches, he wrote the following.

In order to achieve the desired position of the line of thrust, not leaving it to chance, it appears convenient to fix its endpoints at the apex and at the springings. To this end, one has to apply reasonably formed contact surfaces, or convex joints, which will act as hinges, accommodating the deformation of the vault during decentring, as well as the small changes of form under the influence of variations of temperature or one-sided accidental loads. (Heinzerling, 1872: p. 426)

As opposed to his French contemporaries, Heinzerling obviously has permanent hinges in mind which will not be mortared after striking the centre, but remain active to tackle temperature and dynamic loads during the lifetime of the bridge. It is unclear whether Heinzerling, at the time of writing, was already aware of Dupuit's recent book. Anyhow, his extension of the idea to permanent hinging was a significant step forward. Nevertheless, it took almost a decade before the idea was actually put into practice even in Germany, as witnessed by Emil Winkler who commented on the topic in his $1879 / 80$ article on the statics of the masonry arch.

We will now discuss means of ensuring an advantageous position of the line of thrust, some of which have already been tried, some suggested: Firstly, we mention the most radical option, namely, the introduction of hinges at the springings and at the crown, following the construction pattern that has been employed very often in steel bridges. In fact, this technique has already been recommended several times, but, according to our knowledge, it has never been carried out. Typically, one suggests to employ voussoirs of high strength, with rounded or chamfered edges; since it is not 
Engineering History and Heritage

Volume 168 Issue $\mathrm{EH} 2$
Hinges in historic concrete and

masonry arches

Holzer and Veihelmann

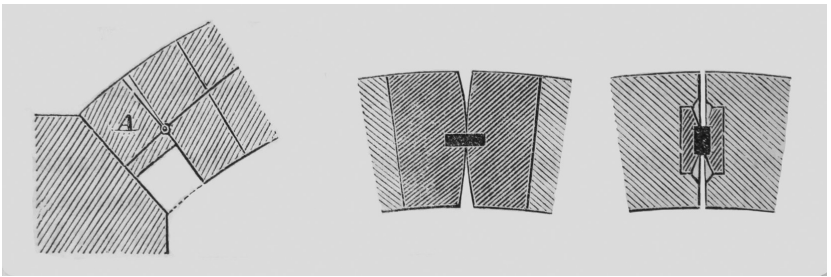

Figure 3. Winkler's proposals for the design of hinges, 1880 (Schäffer and Sonne, 1886: p. 336)

permissible to apply mortar here, one might prevent sliding by iron dowels. Moreover, the application of cast iron or steel plates in a similar arrangement has been suggested. Most of the engineers, however, dislike this construction because the obviously moveable support by small contact surfaces contradicts practical feeling. However, serious concerns about this construction are probably unjustified, provided that the difficulties related to the open joints etc. can be overcome. (Winkler, 1879/1880: p. 59; cf. Figure 3).

In addition to these 'radical' permanent hinges, Winkler also discusses the effects of 'open joints to be mortared after decentring' and 'open joints to be filled before decentring'; that is, techniques of temporary hinging which are more in line with traditional masonry construction. Evidently, Winkler's interest in the idea of hinged masonry arches is deeply rooted in his occupation with structural analysis, rather than in practical aspects of crack prevention.

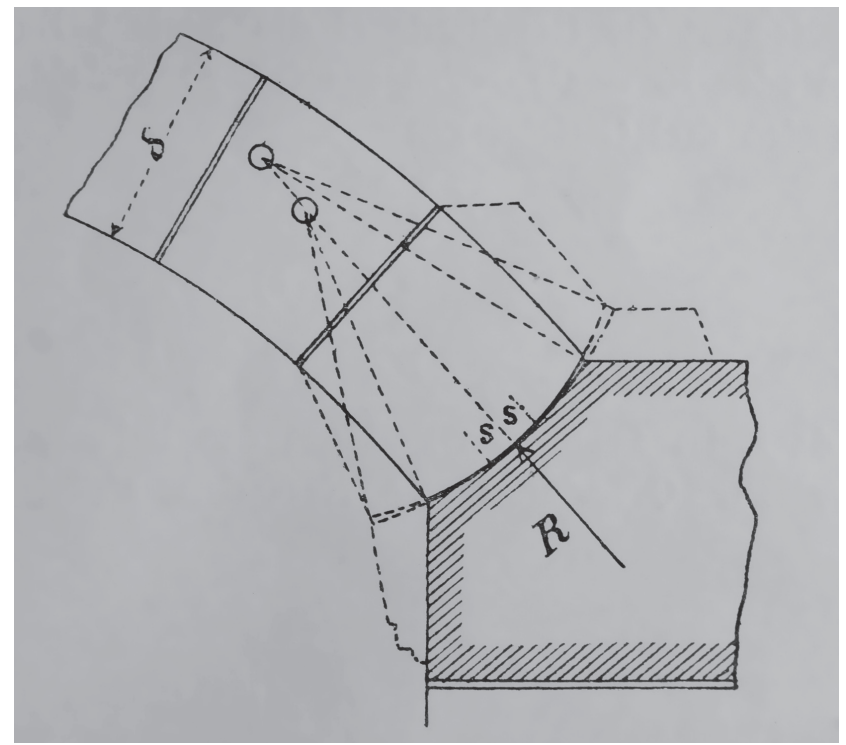

(a)
The first masonry arch bridge with hinges was actually built in 1880 at Langenhennersdorf by Claus Koepcke (1831-1911), engineer in charge of the railways of Saxony. The opening sentence of Koepcke's 1888 report on the topic of hinged masonry arched bridges reads: 'Repeatedly, ashlar arches have given rise to unfavourable experiences, namely, the opening of bed joints and the cracking of edges, particularly at the springings.' (Koepcke, 1888: col. 373). This statement clearly indicates the dominance of practical considerations: avoiding cracks. Koepcke confirms this later in his article: 'As stated at the beginning, the hinges are mainly intended to enable rotations during decentring, without the introduction of unfavourable pressure distributions.' (Koepcke, 1888: col. 375). Like Dupuit and unlike Winkler, Koepcke considered hinges as not very useful during the service life of the bridge: 'The hinge joints have been filled with cement mortar [...]; consequently, the arches have to be considered as clamped; all joints are closed.' (Koepcke, 1888: col. 376). Considering the practical realisation of the hinge joints, Koepcke formed the hinge employing two ashlar blocks, one with a concave surface, the other one with a convex surface with a slightly smaller radius of curvature, so that the idealised contact surface was indeed reduced to a single line (cf. Figure 4). This design resembles somewhat the design of abutment hinges of early steel bridges, where typically a convex pivot is received by a concave counterpart (e.g. the abutment hinges of the Koblenz-Pfaffendorf Bridge).

Karl von Leibbrand (1839-1898) is another early protagonist of hinged vaulted bridges. Leibbrand was obviously unaware of

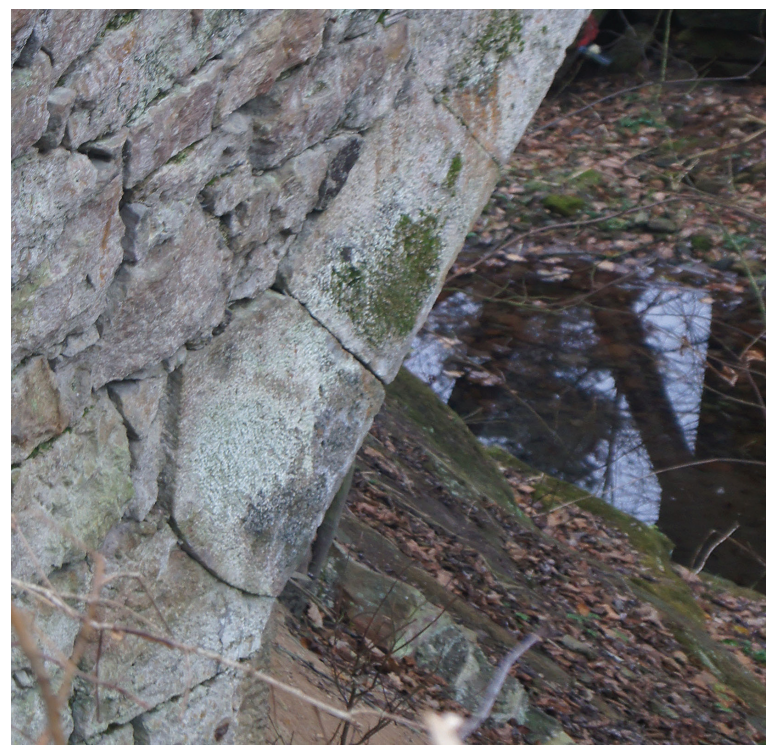

(b)

Figure 4. (a) Sketch of Koepcke's hinge showing the idealised contact line (Heinzerling, 1900: p. 13); and (b) hinge of the bridge at Langenhennersdorf, Saxony 
Engineering History and Heritage

Volume 168 Issue EH2
Hinges in historic concrete and

masonry arches

Holzer and Veihelmann
Koepcke's work, but he does refer to Dupuit's book. Like Koepcke, he was less worried about the perfect matching of the computational model and the actual bridge or the ease of structural analysis, but anxious about practical problems of cracking. In a bridge built without hinges in 1882, Leibbrand had been unable to prevent cracking of the bridge at the springings, even though the execution of the bridge had been carried out very carefully (von Leibbrand, 1888: col. 236). Consequently, he arranged for temporary hinges in his next bridge, the bridge across the Enz at Höfen (1885, destroyed). Unlike Koepcke, Leibbrand did not employ special hinge voussoirs, but created the hinge by simply replacing the mortar in the centre of the joint by a narrow strip of lead, a technique already recommended by Winkler, if suggesting steel strips (Winkler, 1879/1880: p. 60). Leibbrand rather opted for lead because he expected that the pronounced plasticity of the material would guarantee the contact pressure to remain within clearly defined, a priori known limits. After decentring, the remaining parts of the hinge joints were mortared. After positive experiences with the first bridge of this type, Leibbrand executed several other bridges with the same technology. Leibbrand concluded his 1888 report with the following remark.

\begin{abstract}
We have demonstrated that the use of lead inlays in three aptly chosen joints in a bridge arch makes it possible to determine the shape of the line of thrust and the maximum stress on the voussoirs with sufficient accuracy, and that such an arch is enabled to perform the necessary movements during construction and decentring without incurring any damage. Therefore, it is possible to approach the construction of arbitrarily wide spans of masonry bridges in absolute safety. (von Leibbrand, 1888: col. 257)
\end{abstract}

This sounds like a direct echo of Dupuit. Leibbrand's simple constructive solution was as well adapted to masonry construction as Koepcke's more elaborate one. In most bridges where Leibbrand's hinges were applied, they are invisible in the finished state; an exception is shown in Figure 5.

Leibbrand himself characterised the effect of the leaded joints as 'hinge-like'; evidently, they answered their purpose adequately. Conversely, attempts to use asphalt strips (e.g. Westernach Bridge, Erbach/Danube, 1887) or cardboard instead (e.g. Dove Bridge, Berlin, 1911) remained isolated; these hinges did not work properly because the alternative materials did not have sufficient stiffness and strength to enable the reciprocal rotation of the adjoining voussoirs.

\section{From temporary hinges to permanent hinges}

Hinged masonry bridges did not meet with unanimous sympathy, even in Germany, and less so in France. As late as 1899, Georg Christoph Mehrtens, professor of structural analysis at Dresden, denounced hinges bluntly as 'a contrivance

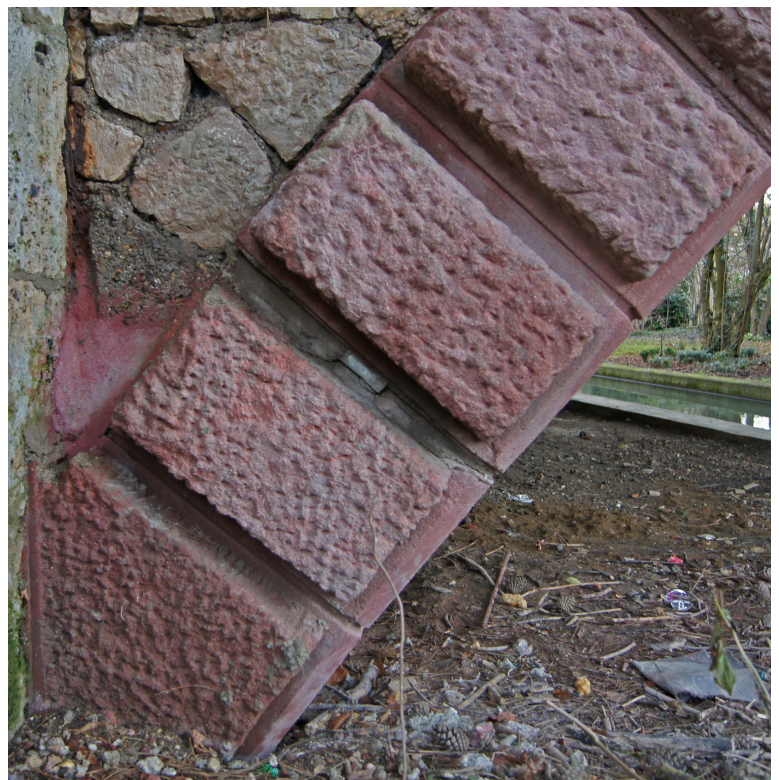

Figure 5. Lead plate hinge at the Schmiech Bridge, Ehingen, 1895

which is alien to the masonry arch and incompatible with it' (Landsberg, 1899: p. 308). Particular scepticism was stirred by the application of open, permanent hinges. Doubts were voiced, for example, by one of France's doyens in bridge building, Philippe Croizette-Desnoyers. In his prestigious 1885 course on bridge building, he wrote the following.

The system of hinges presents advantages, and it can be expected that their use will increase more and more in metal bridges, provided they are employed with prudence. However, it seems that these considerations are inapplicable to masonry bridges. $1^{\circ}$, one will be unable to match the contact surface of the bolt with the section of the arc, as in metal bridges; $2^{\circ}$, unlike a metal arch, masonry does not form a homogeneous and perfectly joined mass; $3^{\circ}$, finally, the movability which characterises hinged systems is essentially contrary to the nature of masonry which requires a great fixity and whose resistance fails to grow with time unless that fixity is provided. (Croizette-Desnoyers, 1885: pp. 325-326)

Notwithstanding these reluctant feelings, permanent hinges were actually realised in Germany by Max Leibbrand (1851-1925) at the bridge across the Danube at Inzigkofen, completed in 1895 (destroyed). Whereas Koepcke, as well as Karl von Leibbrand (not a close relative of Max Leibbrand), had primarily addressed the prevention of cracks with their temporary hinges, Max Leibbrand was particularly impressed by the idea of a perfect match between theory and reality: 'There is no reason to be satisfied with an approximation, since there is a well-defined static task.' (Leibbrand, 1895/1896: p. 67). The permanent hinges of Max Leibbrand's Inzigkofen Bridge were iron knuckle pin 
Engineering History and Heritage

Volume 168 Issue EH2
Hinges in historic concrete and

masonry arches

Holzer and Veihelmann hinges. They remained open and visible even in the completed state of the bridge, thus emphasising the perfect analogy to isostatic three-hinged iron arches.

Structural optimisation of the hinged arch, no matter which material is employed, automatically entails some characteristic shape features. Among these, the 'banana-shape' of the haunches is perhaps the most distinctive. Close to the hinges, the thickness of the individual 'voussoirs' can be rather small, whereas the arch has to be thickest in the middle between the hinges because it will have to carry the highest bending stress here. In order to reduce the total weight of the arch, and consequently its lateral thrust, this structurally optimal shape is also a practically desirable one and furthermore helps to economise on material. While contemporary engineers readily accepted these features with steel bridges such as Eiffel's twohinge bridge at Porto, they were less prepared to encounter them in masonry bridges: as late as 1911, Joseph Melan, a supporter of hinged bridges, admitted as a slight drawback 'the unaesthetic shape of the three-hinged arch, which assumes its maximum thickness, according to static requirements, in the middle of the haunches, rather than at the springings' (Melan, 1911: p. 203).

Furthermore, permanent hinges also called for dilation joints in the superstructure of the bridge.

\footnotetext{
Above the hinge joints, gaps were left open in the masonry or concrete, in order to permit unrestricted movements of the vault under the increasing load; these gaps were only left open until the hinge joints had been filled up completely with mortar, besides the lead inlay [...]. The above-mentioned gaps in the spandrels and the remaining superstructure, enabling movements caused by temperature variations, have been left open permanently in later bridges. (von Leibbrand, 1897: p. 48)
}

The dilation joints and hinges, considered aesthetically displeasing, were frequently hidden in recesses. Often, a cladding of the whole structure negated its modern isostatic structure.

With a view to architectonic appearance, it was required that the hinges should be invisible. The hinge at the apex could conveniently be concealed by a coat of arms; the hinges at the abutments were withdrawn a little bit behind the abutment wall, thus hiding them without effort. (Sager and Woerner, 1925: p. 13)

\section{Designing the hinge}

Koepcke's hinge design lent itself not only to temporary hinges but also to permanent ones, by simply omitting the mortaring. While Koepcke's earliest hinge voussoirs were made of sandstone, later examples typically employ granite. The contractors Dyckerhoff and Widmann, who were very active in the construction of concrete arch bridges without reinforcement during the last decennium of the nineteenth century, employed permanent stone hinges, for example, at the railway viaduct at Chemnitz (1899) and at the bridge across the Eyach creek at Owingen from 1905 (Figure 6). However, it may be doubted whether such hinges, when filled with accumulated dust, still perform properly after decades of service life.

Naturally, concrete contractors would quickly try to substitute expensive ashlar hinge voussoirs by cheaper cast concrete ones. Concrete hinge voussoirs could be produced with high geometric accuracy and with well-controlled quality, at low cost. The first concrete hinge blocks were presumably those of Dyckerhoff's inundation viaduct of St Mary's Bridge, Dresden (1894-1896). They were conceived as permanent hinges. Some of the original arches of the viaduct are preserved, but the permanent hinges are clad with sandstone. Further, slightly later examples which are well preserved may be found on some Saxon railway lines, such as Limbach-Wüstenbrand (1896-1897) and Altenburg-Langenleuba (1899-1901), some with visible hinges (Figure 7).

Extensive testing of concrete hinge blocks was performed on Dyckerhoff's initiative in 1895/1896 at the Prussian materials testing laboratories at Berlin-Charlottenburg (BWA, undated: Number 422). The Koepcke-type hinge employing stone or concrete voussoirs with curved surfaces typically failed by tensile cracking - that is, splitting of the hinge blocks orthogonal to the

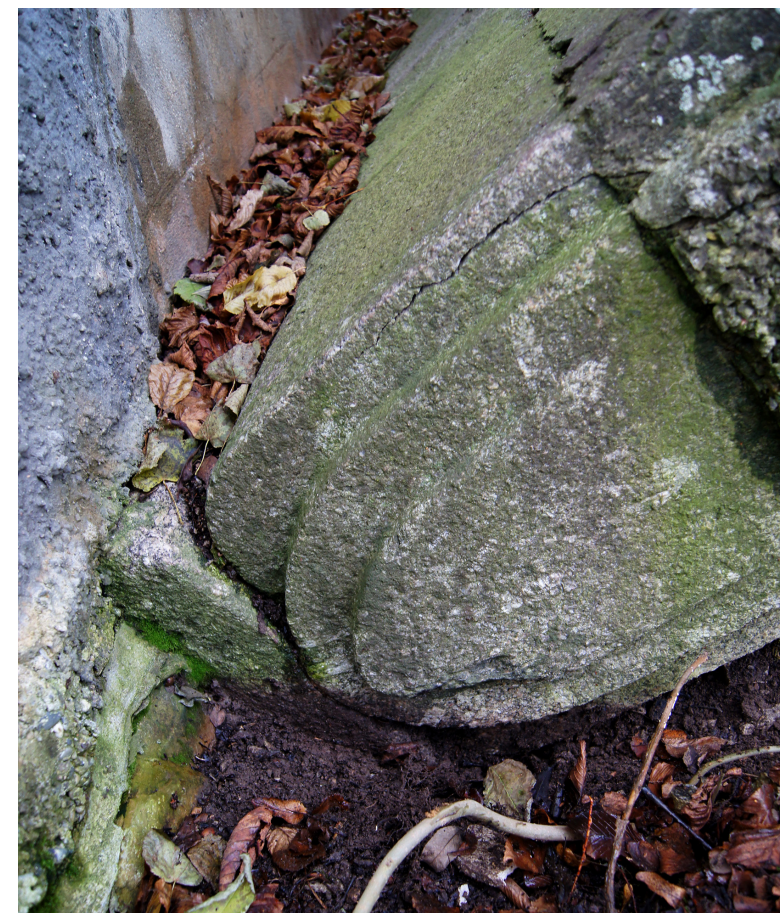

Figure 6. Stone hinge at the bridge across the Eyach, Owingen, 1905 
Hinges in historic concrete and

masonry arches

Holzer and Veihelmann

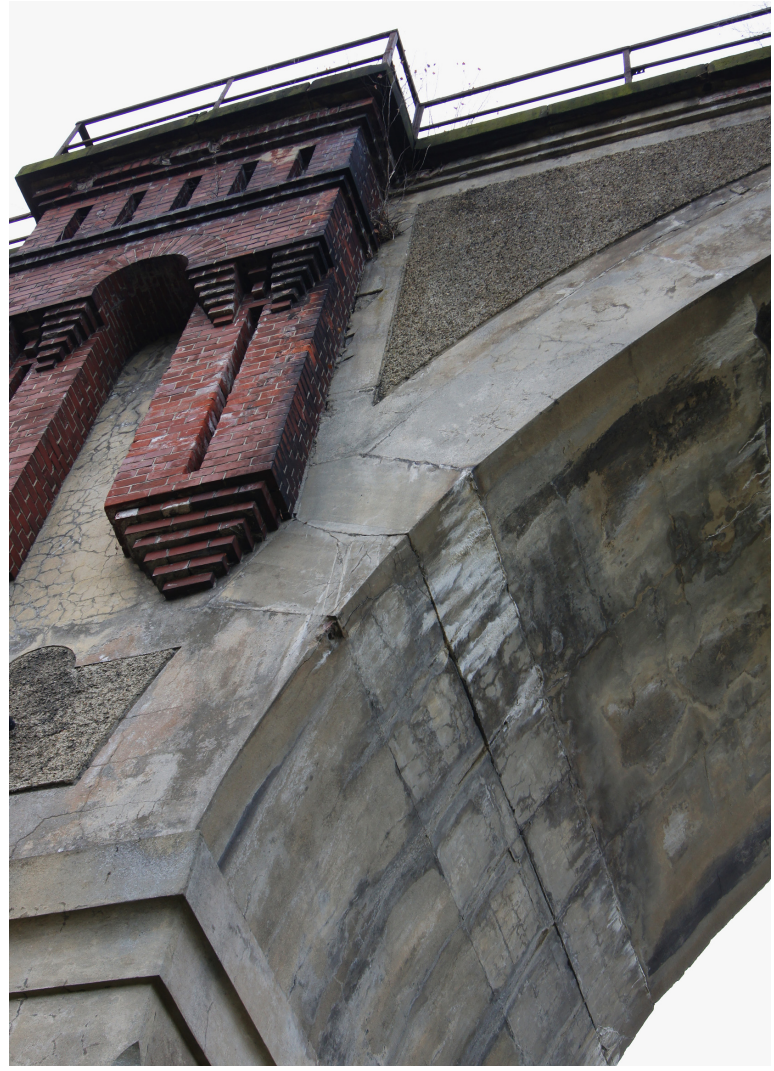

Figure 7. Concrete hinge voussoirs at a viaduct of the railway line Altenburg-Langenleuba (1899-1901)

contact surface, rather than by compressive crushing. Therefore, it was natural to reinforce the hinge blocks with transversal iron bars. Surprisingly, this suggestion met with scepticism at first because engineers were concerned that the reinforcement might be displaced or damaged during the ramming of the concrete. Reinforced concrete hinge blocks were applied, for example, at August's bridge, Dresden (1907-1910). The hinges were the only reinforced parts of the bridge, while the arch itself was built in rammed concrete without reinforcement. A few years later, Joseph Melan summarised the application of reinforced hinge blocks as follows.

In some recent projects, the hinge blocks have been reinforced with iron in order to increase their compressive strength. It appears advantageous to employ closed stirrups or spiral coiling; however, even simple reinforcement bars arranged orthogonally to the direction of compression will suffice. (Melan, 1911: pp. 209-210)

As opposed to stone hinges, iron hinges may have appeared preferable to some engineers since they allowed friction to be reduced by lubrication, and called for little maintenance if protected against corrosion. The first iron hinge in a concrete arch bridge was employed by Karl von Leibbrand, the former protagonist of lead inlays, in 1893 at the bridge across the Danube at Munderkingen. The hinges employed here were rolling contact hinges: the two surfaces in contact were curved, one with a concave shape, receiving a convex counterpart with a slightly greater curvature.

At the Munderkingen bridge, the lead inlays would have yielded too much under the extremely high pressure, or one would have been forced to use strips of considerable width; therefore, actual iron and steel hinges have been applied. (Gugenhan, 1894: p. 493)

These hinges were filled after decentring.

These hinges might well have been left open and visible, proper supervision and control provided; however, the maintenance of the bridge falling within the responsibility of the community, it has been preferred to fill the hinges with cement mortar with a mixture of 1 part cement to 2 parts of sand, after having eased the centre and the arch having come to a rest. (Gugenhan, 1894: p. 493)

However, steel hinges held a problem: the sliding of the hinge at the contact line. Smooth metal surfaces, combined with the application of lubricating and anticorrosive grease, resulted in a reduced friction coefficient in the contact zone, causing sliding failure of the hinge, in the worst case entailing the collapse of the whole bridge. Early hinged iron arch bridges such as the KoblenzPfaffendorf Bridge had provided for this by the addition of safety barbs. By contrast, the hinges of the two-span Maximilian Bridge at Munich (1904) dispensed with such expedients and relied on the pure theoretical form of the hinge, with dramatic consequences: both arches of the ashlar bridge slid out of the hinges shortly after the centre had been struck. The total loss of the bridge was only prevented by the centres which were still in place. The larger part of the ashlar voussoirs could thus be salvaged and reused in the reconstruction of the bridge (for a description see Dietz (1904) and Mörsch (1905)).

Another sliding failure occurred at almost the same time at the bridge over the Iller at Lautrach, 1903-1904 (Figure 8). This three-hinge concrete arch started to slide at the abutments when the centre was struck (Liebold, 1904: p. 454). However, the sliding stopped by itself at a displacement of about $17 \mathrm{~mm}$. Subsequently, the displaced hinge was marked and observed. The marks then incised into the hinge to indicate its displaced position are still visible today (Figure 8). After the investigation, the bridge was deemed safe regardless of the sliding. This assessment was obviously correct since no further sliding is visible today, after a service life of more than a century. The Lautrach Bridge is a nice example that a historic structure that has 'failed' by modern standards may still fulfil its purpose perfectly well.

Nevertheless, the collapse of the Maximilian Bridge alerted engineers. Dowels inserted into the contact surface became 
Engineering History and Heritage

Volume 168 Issue EH2
Hinges in historic concrete and

masonry arches

Holzer and Veihelmann

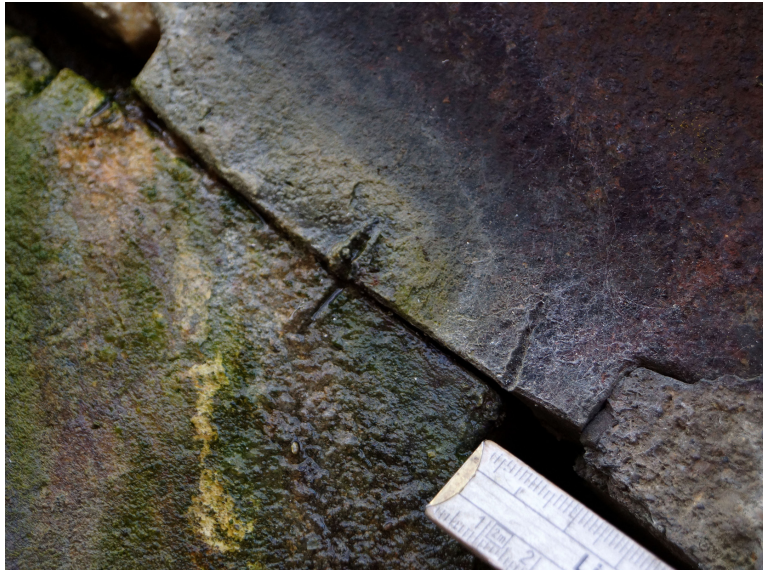

Figure 8. Displaced steel hinge of the Iller Bridge at Lautrach, showing the control marks

mandatory in the following years. These dowels were designed to carry the shear force in the hinge, irrespective of the actual frictional load-carrying capacity of the joint.

However, other hinge types were perhaps even safer and more logical. Among these, the knuckle pin hinge is the most important. This hinge is constituted by a cylindrical bolt which is clasped by two concave surfaces that are free to rotate around it. Unlike the other hinge types of the time, this hinge is intrinsically capable of transferring shear forces and preventing sliding, and it will transmit shear by a pressure distribution. The knuckle pin hinge was first applied at the Inzigkofen Bridge which has already been mentioned as the first permanently hinged vaulted bridge (1895). The Inzigkofen Bridge was destroyed in World War II, but a number of similar bridges have been preserved at Munich. Here, almost all the bridges across the Isar were destroyed in 1899 by an unprecedented flood disaster. All of the replacement bridges were hinged, including the unfortunate Maximilian Bridge. The Prince Regent's Bridge (erected 1900-1901) has knuckle pin hinges, if clad and hidden from view. By a lucky coincidence, insufficient maintenance has caused the cladding to drop off from Berlin's slightly later, but very similar Prince Regent's Bridge at Wilmersdorf (1907; Figure 9). This unwittingly exposed knuckle pin hinge permits a nice insight not only into the construction of the hinge itself but also into the way it is joined to the concrete arch.

By the end of the nineteenth century, reinforced concrete began to replace masonry or rammed concrete as the main building material for vaulted bridges. The new construction language associated with reinforced concrete also saw the introduction of new hinge types, notably the Mesnager and Freyssinet hinges. These hinge types are beyond the scope of the present paper.

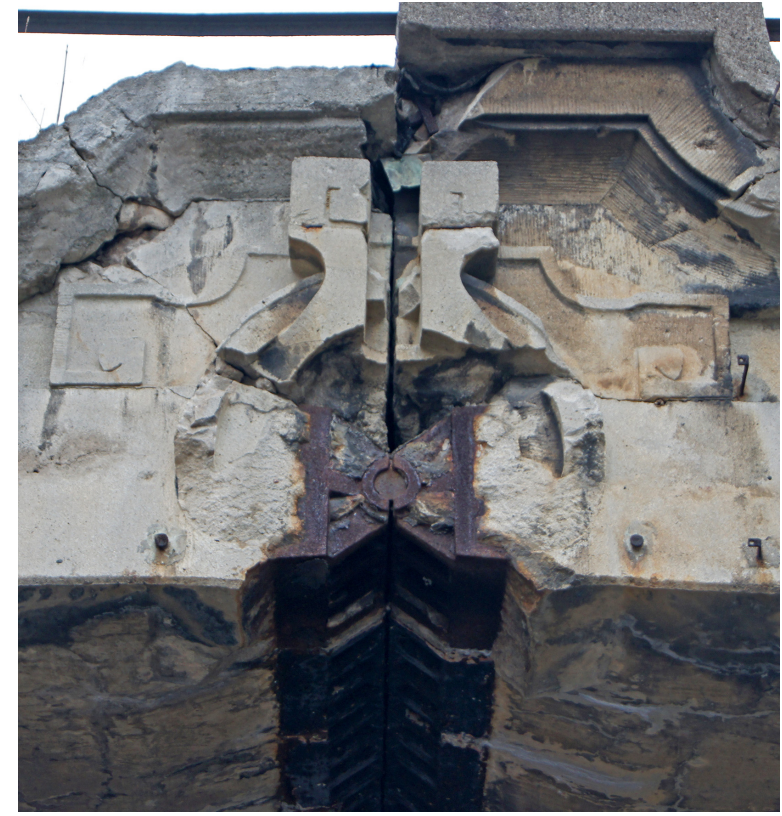

Figure 9. Knuckle pin hinge of the Prince Regent's Bridge at Berlin-Wilmersdorf, 1907

\section{Conclusions}

The present contribution has highlighted the wide range of possible solutions for the introduction of hinges in masonry bridges around the end of the nineteenth century and the beginning of the twentieth century. An engineer who is called today to assess the load-carrying capacity of such an historic bridge should be conscious that, notwithstanding the fact that the bridge does not exhibit any hinges in its finished state, it may have been built essentially as a three-hinged structure, so that only the accidental loads act on a monolithic clamped arch, whereas permanent loads are carried by a three-hinged arch. Failure to notice this important fact may lead to a totally inadequate assessment, for example, indicating excessive edge pressure. On the other hand, a bridge that appears, on first sight, as a perfect three-hinged arch, may perform as a clamped arch because the historic hinge technology may perform inadequately. Constructions such as strips of asphalt or lead inserted into the hinge joint may effectively block rotations rather than encourage them; the same can be true for metal knuckle hinges subject to corrosion. An in-depth analysis of the historic source material, as well as the current state of the hinges, is therefore an indispensable prerequisite of a diligent assessment of a historic masonry arch bridge. It is by no means satisfactory or sufficient to input the bridge as seen today into a computer program, apply the loads, and take the results of the stress analysis as a basis for decisions on rehabilitation or destruction.

\section{REFERENCES}

Boistard LC (1810) Expériences sur la stabilité des voûtes. In Recueil de Divers Mémoires Extraits de la Bibliothèque Impériale des 
Ponts et Chaussées (Lesage PC (ed.)), 2nd edn. Firmin Didot, Paris, France, vol. II, pp. 171-217. (in French)

Brosselin G (1878) Note sur la Construction des Ponts en Maçonnerie. Archives de l'École Nationale des Ponts et Chaussées, Paris, France, sign. $4^{\circ} 12538 / C 705$. (in French)

BWA (undated) Archive of the contractors Dyckerhoff and Widmann AG, Munich. Bayerisches Wirtschaftsarchiv, sign. BWA F100.

Claudel J and Laroque L (1850) Pratique de l'Art de Construire. Carilian-Gœury et Victor Dalmont, Paris, France. (in French)

Croizette-Desnoyers P (1885) Cours de Construction des Ponts. Dunod, Paris, France, vol. 2. (in French)

Darcel J (1855) Ponts en ciment. Annales des Ponts et Chaussées, 3rd series IX(1): 252-255. (in French)

Debauve A (1873) Manuel de l'Ingénieur des Ponts et Chaussées, Vol. 10, Ponts en Maçonnerie. Dunod, Paris, France. (in French)

Dejardin GA (1845) Routine de l'Etablissement des Voûtes. CarilianGœury et Victor Dalmont, Paris, France. (in French)

Dietz W (1904) Der Bauunfall der äußeren Maximiliansbrücke in München. Zeitschrift des Vereins deutscher Ingenieure 48(38): 1407-1411. (in German)

Dupuit J (1870) Traité de l'Equilibre des Voûtes et de la Construction des Ponts en Maçonnerie. Dunod, Paris, France. (in French)

Durand-Claye A (1867) Note sur la vérification de la stabilité des voûtes en maçonnerie et sur l'emploi des courbes de pression. Annales des Ponts et Chaussées, 4th series XIII(1): 63-96. (in French)

Gugenhan (1894) Beton-Brücke über die Donau bei Munderkingen. Deutsche Bauzeitung 28(80): 493-495. (in German)

Heinzerling F (1872) Analytisch-graphische Construction der Brückengewölbe mit Berücksichtigung ihrer größten einseitigen Belastung. Zeitschrift für Bauwesen 22(8-10, 1112): 423-448, 559-574. (in German)

Heinzerling F (1900) Steinerne Brücken, 2nd edn. Loewenthal, Berlin, Germany. (in German)

Holzer S (2012) Innovation in 19th century vaulted bridge construction. In Nuts and Bolts of Construction History. Proceedings of the 4th International Conference on Construction History (Carvais R, Guillerme A, Nègre V and Sakarovitch J (eds)). Picard, Paris, France, vol. 3, pp. 589-597.

Koepcke C (1888) Über die Verwendung von drei Gelenken in Steingewölben. Zeitschrift des Architekten- und IngenieurVereins zu Hannover 34: 373-380. (in German)

Landsberg T (1899) Handbuch der Ingenieurwissenschaften, vol. 2, Der Brückenbau, 3rd edn. Engelmann, Leipzig,

Germany. (in German)

Leibbrand M (1895/1896) Beton-Brücke mit offenen Gelenken über die Donau bei Inzigkofen. Monatsschrift des württembergischen Vereins für Baukunde, 65-70, 73-78. (in German)

Liebold B (1904) Eisenbahnbrücke in Stampfbeton über die
Iller bei Lautrach (Bayr. Schwaben). Deutsche Bauzeitung 38(71): 441-443; 38(73): 453-454. (in German)

Lorenz W (1990) Die Entwicklung des Dreigelenksystems im 19. Jahrhundert. Stahlbau 59(1): 1-10. (in German)

Mantion FHD (1860) Étude de la partie métallique du pont construit sur le canal Saint-Denis. Annales des Ponts et Chaussées, 3rd series XX(2): 161-251. (in French)

Melan J (1911) Der Brückenbau, Vol. 2, Steinerne Brücken und Brücken aus Beton und Eisen. Deuticke, Leipzig, Germany. (in German)

Méry E (1840) Mémoire sur l'équilibre des voûtes en berceau. Annales des Ponts et Chaussées, 1st series $\mathbf{X}(\mathbf{1})$ : $50-70$. (in French)

Mörsch E (1905) Die Rekonstruktion der Maximiliansbrücke in München. Schweizerische Bauzeitung 45(19): 236-239. (in German)

Sager and Woerner (1925) Bauunternehmung Sager \& Woerner G. m. b. H. Entwurf und Ausführung von Tief- und Hochbauten aller Art. G. Franz, Munich, Germany. (in German)

Schäffer T and Sonne E (eds) (1886) Handbuch der Ingenieurwissenschaften, Vol. 2, Steinerne und hölzerne Brücken, 2nd edn. Engelmann, Leipzig, Germany. (in German) Séjourné $\mathrm{P}$ (1886) Construction des Ponts du Castelet, de Lavaur et Antoinette. Annales des Ponts et Chaussées, 6th series XII(2): 409-549. (in French)

Séjourné P (1913) Grandes Voûtes, Vol. 4, Voûtes Articulées. Tardy-Pigelet, Bourges, France. (in French)

Tolkmitt G (1895) Leitfaden für das Entwerfen und die Berechnung gewölbter Brücken. Ernst \& Sohn, Berlin, Germany. (in German)

von Leibbrand K (1888) Steinbrücken mit gelenkartigen Einlagen. Zeitschrift für Bauwesen 38(4-6): 235-260. (in German)

von Leibbrand K (1897) Gewölbte Brücken. Engelmann, Leipzig, Germany, Fortschritte der Ingenieurwissenschaften 2nd group, vol. 7. (in German)

Winkler E (1879/1880) Lage der Stützlinie im Gewölbe. Deutsche Bauzeitung 13(23): 117-119; 13(25): 127-130; 14(11): 58-60. (in German)

\section{WHAT DO YOU THINK?}

To discuss this paper, please email up to 500 words to the editor at journals@ice.org.uk. Your contribution will be forwarded to the author(s) for a reply and, if considered appropriate by the editorial panel, will be published as discussion in a future issue of the journal.

Proceedings journals rely entirely on contributions sent in by civil engineering professionals, academics and students. Papers should be 2000-5000 words long (briefing papers should be 1000-2000 words long), with adequate illustrations and references. You can submit your paper online via www.icevirtuallibrary.com/content/journals, where you will also find detailed author guidelines. 